\title{
Synthesis of the aglycon of scorzodihydrostilbenes B and D
}

\author{
Katja Weimann and Manfred Braun ${ }^{*}$
}

\author{
Full Research Paper \\ Address: \\ Institute of Organic and Macromolecular Chemistry, \\ Heinrich-Heine-University Düsseldorf, Universitätsstr. 1, D-40225 \\ Düsseldorf, Germany \\ Email: \\ Manfred Braun* - braunm@hhu.de \\ * Corresponding author \\ Keywords: \\ $\mathrm{C}-\mathrm{H}$ activation; hydroarylation; phenols; regioselectivity; ruthenium
}

\author{
Beilstein J. Org. Chem. 2019, 15, 610-616. \\ doi:10.3762/bjoc. 15.56 \\ Received: 09 December 2018 \\ Accepted: 15 February 2019 \\ Published: 06 March 2019 \\ Associate Editor: L. Ackermann \\ (c) 2019 Weimann and Braun; licensee Beilstein-Institut. \\ License and terms: see end of document.
}

\begin{abstract}
Benzyl- and methyl-protected 2,4-dihydroxyacetophenones are added under ruthenium catalysis to 4-methoxy- and 3,4dimethoxystyrene in a completely regioselective manner. Thus, oxygenated dihydrostilbenes are obtained that feature the skeleton of scorzodihydrostilbenes - antioxidative agents that were recently isolated from Scorzonera radiata. Selective deprotection liberates the corresponding phenols, among them the aglycon of scorzodihydrostilbenes B and D.
\end{abstract}

\section{Introduction}

Among phytochemicals with strong allelopathic effects, various natural products are found that feature the structural motif of dihydrostilbene with multiple phenolic functionality. These natural products that form as secondary metabolites on a branch of flavonoid biosynthesis found wide interest for their various biological effects like anti-oxidative and biofouling-preventing activity [1]. From crude extracts of the Mongolian medicinal plant Scorzonera radiata, that is used in folk medicine for the treatment of poisonous ulcers, fever, and various other diseases [2-4], five new dihydrostilbenes, named scorzodihydrostilbenes A-E (1-5), were isolated in 2009 and their structures were determined (Scheme 1) [5]. They all are $\beta$-glucosides with highly oxygenated aryl rings. Scorzodihydrostilbene E (5) features a dimeric skeleton that originates from an oxidative coupling of compound $\mathbf{1}$. The natural products exhibited antioxidative activ- ity that was partly stronger than that of the well-known naturally occurring antioxidant resveratrol [5]. In this article, we describe a synthetic approach that takes advantage of a regioselective, ruthenium-catalyzed $\mathrm{C}-\mathrm{H}$ activation [6] and makes accessible not only the skeleton of dihydrostilbenes with multiple phenolic ether functionality but also the aglycon of scorzodihydrostilbenes $B$ and $D\left(2\right.$ and $\mathbf{4}, R^{1}=R^{2}=H$, instead of $\beta$-glycosyl, respectively).

\section{Results and Discussion}

Most syntheses of dihydrostilbenes rely on a carbonyl olefination followed by hydrogenation of the stilbene [7-9]. However, this route appeared not attractive, particularly as our attempts to hydrogenate highly substituted stilbenes that would serve as the precursors of scorzodihydrostilbenes had failed, presumably 
<smiles>[R]COc1ccc(O[R2])c(CCc2ccc(O[R2])c([R])c2)c1C(C)=O</smiles>

1: $R^{1}=\beta$-glucosyl, $R^{2}=H, R^{3}=O M e, R^{4}=H$

2: $R^{1}=\beta$-glucosyl, $R^{2}=H, R^{3}=O M e, R^{4}=M e$

3: $R^{1}=\beta$-glucosyl, $R^{2}=H, R^{3}=H, R^{4}=H$

4: $R^{1}=H, R^{2}=\beta$-glucosyl, $R^{3}=O M e, R^{4}=M e$<smiles>[R]Oc1ccc(O)c(CCc2cc(OC)c(O)c(-c3cc(CCc4c(O)ccc(O[R])c4C(C)=O)cc(OC)c3O)c2)c1C(C)=O</smiles>

$\mathrm{HO}$<smiles>COc1cc(C=Cc2ccccc2)cc(OC)c1</smiles>

resveratrol

5: $R=\beta$-glucosyl

Scheme 1: Structures of scorzodihydrostilbenes A-E (1-5) and resveratrol.

due to steric hindrance caused by the accumulation of substituents at the acetophenone moiety [10]. We felt that a straightforward access to the scorzodihydrostilbene aglycons would be possible by using the transition metal-mediated, regioselective, chelation-directed activation of an aryl-hydrogen bond. A promising approach was seen in an application of Murai's elegant ruthenium-catalyzed ortho-functionalization of aryl alkyl ketones and their addition to olefins [11-15]. This route appeared particularly attractive as it leads in an atom-economic manner directly to the carbon skeleton of scorzodihydrostilbenes, starting from suitably substituted acetophenone and styrene derivatives. Furthermore, Murai's protocol offers another advantage: the regioselective formation of the antiMarkovnikov product. Here, a modified version based upon an in situ generation of the ruthenium complex described by Genet and Darses [16] was applied.

Thus, O-protected 2,5-dihydroxyacetophenones 6 were submitted to a hydroarylation reaction with two equivalents of styrenes 7 in the presence of $\left[\mathrm{Ru}(p \text {-cymene }) \mathrm{Cl}_{2}\right]_{2}$ and $\mathrm{P}\left(4-\mathrm{CF}_{3} \mathrm{C}_{6} \mathrm{H}_{4}\right)_{3}$. The reactions were performed with sodium formate in toluene in a sealed tube at $140-150{ }^{\circ} \mathrm{C}$. Reaction times of 7 to 10 days turned out to be necessary. Thus, dihydrostilbenes $\mathbf{8 a}-\mathbf{c}$ were obtained in fair yields in a single step, whereas in the case of the tetramethoxy-substituted derivative 8d, the yield was lower (Scheme 2).

In order to bring about the cleavage of the benzyl protecting groups in the ketones $\mathbf{8 a}$ and $\mathbf{8 b}$ by hydrogenolysis [17,18], various metal catalysts were tested. It turned out that palladium on charcoal was the only catalytic system that provided satisfying results. Ethyl acetate was found to be the appropriate solvent, whereas the starting materials did not dissolve in methanol or ethanol. The reaction required a hydrogen overpressure of 3 bar for one to three days at room temperature, but even then, the deprotection was not completed in all cases. On the other hand, partial hydrogenation of the aromatic rings had to be suppressed. Nevertheless, the aglycon 9 of scorzodihydrostilbenes B and D ( 2 and $\mathbf{4}$ ) was obtained in good yield from $\mathbf{8 a}$. Hydrogenolysis of ketone $\mathbf{8 b}$ led to hydroquinone $\mathbf{1 0}$, however, along with a minor amount of mono-deprotected phenol $\mathbf{1 1}$. The main product $\mathbf{1 0}$ was isolated in pure form by column chromatography, whereas the fraction containing the phenol 11 was still contaminated with hydroquinone 10 (Scheme 3).<smiles>[M]C(=O)c1cc([R])ccc1[R]</smiles>

$$
\begin{aligned}
& \text { 6a: } R^{1}=R^{2}=O B n \\
& \text { 6b: } R^{1}=O M e, R^{2}=O B n \\
& \text { 6c: } R^{1}=R^{2}=O M e
\end{aligned}
$$

2<smiles>[R]c1cc(C=C)ccc1OC</smiles>

7a: $R^{3}=\mathrm{OMe}$

7b: $\mathrm{R}^{3}=\mathrm{H}$
$\left[\mathrm{Ru}(p \text {-cymene }) \mathrm{Cl}_{2}\right]_{2}(2.5 \mathrm{~mol} \%)$ $\mathrm{P}\left(4-\mathrm{CF}_{3} \mathrm{C}_{6} \mathrm{H}_{4}\right)_{3}(15 \mathrm{~mol} \%)$ $\mathrm{HCO}_{2} \mathrm{Na}$

toluene; $140-150^{\circ} \mathrm{C}, 7-10 \mathrm{~d}$

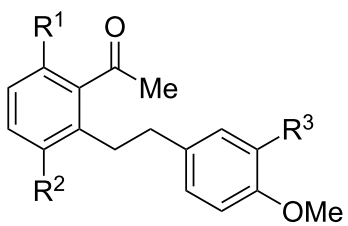

8a: $R^{1}=R^{2}=O B n, R^{3}=O M e$

8b: $R^{1}=R^{2}=O B n, R^{3}=H$

8c: $R^{1}=O M e, R^{2}=O B n, R^{3}=H$

8d: $R^{1}=R^{2}=R^{3}=O M e$ 
<smiles>COc1ccc(CCc2c(OCc3ccccc3)ccc(OCc3ccccc3)c2C(C)=O)cc1OC</smiles>

$8 a$<smiles>COc1ccc(CCc2c(OCc3ccccc3)ccc(OCc3ccccc3)c2C(C)=O)cc1</smiles>

$8 b$
$\mathrm{H}_{2}, \mathrm{Pd} / \mathrm{C}$

3 bar, $25^{\circ} \mathrm{C}$ EtOAc, $72 \mathrm{~h}$

3 bar, $25^{\circ} \mathrm{C}$ EtOAc, $25 \mathrm{~h}$<smiles>COc1ccc(CCc2c(O)ccc(O)c2C(C)=O)cc1OC</smiles>

$9(75 \%)$<smiles>[R]Oc1ccc(O)c(C(C)=O)c1CCc1ccc(OC)cc1</smiles>

10: $\mathrm{R}=\mathrm{H}(65 \%)$

11: $R=B n(16 \%)$

Scheme 3: Cleavage of benzyl protecting groups in ketones $\mathbf{8 a}$ and $\mathbf{8 b}$. Synthesis of scorzodihydrostilbene aglycon 9

Finally, the glycosylation of the aglycon 9 was briefly studied using Helferich's method [19]. It turned out that, upon treatment of 9 with $\beta$-D-glucose pentaacetate in the presence of an excess of boron trifluoride etherate [20], a regioselective reaction occurred at the phenolic group in ortho-position to the alkyl side chain to give mono-glycosylated product $\mathbf{1 2}$. Chelation of the carbonyl and the neighboring phenolic group by the Lewis acid is assumed to be responsible for this regiochemical outcome. The ${ }^{1} \mathrm{H}$ NMR spectrum of $\mathbf{1 2}$ clearly indicates - by the low-field shift of the phenolic hydrogen chelated with the carbonyl group - that glycosylation had not occurred at this position. Unfortunately, however, the $\alpha$-anomer 12 formed exclusively, so that, after cleavage of the ester groups, epi-scorzodihydrostilbene D (13) was obtained as single stereoisomer (Scheme 4).

Obviously, the conditions required in the glycosylation reaction - excess of the Lewis acid and elongated reaction time resulted in the formation of the thermodynamically favored $\alpha$-anomer (for details, see Experimental Part and Supporting
Information File 1). Attempts aimed at synthesizing the natural $\beta$-anomeric scorzodihydrostilbenes A-D are pursued.

\section{Conclusion}

In summary, a straightforward procedure for the synthesis of dihydrostilbenes with multiple phenolic substitutions was opened based upon Murai's ruthenium-catalyzed hydroarylation of olefins. Thus, the aglycon of scorzodihydrostilbene D became accessible in two steps from readily available starting materials.

\section{Experimental}

General: Melting points (uncorrected) were determined with a Büchi 540 melting point apparatus. NMR spectra were recorded with Bruker DXR 600 and DXR 300 spectrometers. Mass spectra were recorded on ion-trap API mass spectrometer Finnigan LCQ Deca (ESI), triple-quadrupole-mass spectrometer Finnigan TSQ 7000, and sector field mass spectrometer Finnigan MAT 8200 (EI, 70 eV), Thermo Finnigan TraceGC Ultra (GC-MS). Column chromatography was performed with<smiles>COc1ccc(CCc2c(O)ccc(O)c2C(C)=O)cc1OC</smiles>

9

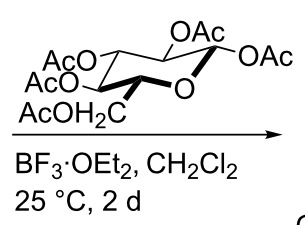

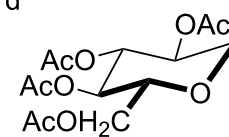<smiles>CCOc1ccc(O)c(C(C)=O)c1CCc1ccc(OC)c(OC)c1</smiles><smiles>CC(O)C(O)C(O)C(O)C(C)O</smiles>

13 
Fluka silica gel 60 (230-400 mesh) and thin-layer chromatography was carried out by using Merck TLC Silicagel 60F254 aluminium sheets. Tetrahydrofuran (THF) and toluene were refluxed under nitrogen over sodium wire and a small amount of benzophenone until the dark blue color of the solution persisted. Then, the solvents were distilled under nitrogen and taken from the distillation flask, which was closed by a septum, by syringes or cannulas. 2,5-Dimethoxyacetophenone (6c) and 4-methoxystyrene (7b) were purchased from Sigma-Aldrich. 2,5-Dibenzyloxyacetophenone (6a) was prepared from commercially available 2,5-dihydroxyacetophenone according to [21].

1-(5-Benzyloxy-2-methoxyphenyl)ethan-1-one (6b): A mixture of commercially available 5-hydroxy-2-methoxyacetophenone $(1.0 \mathrm{~g}, 6.0 \mathrm{mmol}), \mathrm{K}_{2} \mathrm{CO}_{3}(1.24 \mathrm{~g}, 9.0 \mathrm{mmol})$, benzyl bromide $(2.05 \mathrm{~g}, 12.0 \mathrm{mmol})$ and DMF $(14 \mathrm{~mL})$ was stirred at $25^{\circ} \mathrm{C}$ for $5 \mathrm{~h}$. After acidification with $5 \%$ hydrochloric acid, the mixture was extracted with three $15 \mathrm{~mL}$ portions of ethyl acetate. The combined organic layers were washed with brine, the solvent was removed in a rotary evaporator and the residue was purified by column chromatography (silica gel; ethyl acetate $/ n$-hexane, 1:9) to give white, crystalline product $\mathbf{6 b}$ in $99 \%$ yield (1.518 g). The spectroscopic data agree with those described in the literature [21].

1,2-Dimethoxy-4-vinylbenzene (7a): A $100 \mathrm{~mL}$ two-necked flask was equipped with a reflux condenser, a magnetic stirrer and a connection to a combined nitrogen-vacuum line, charged with sodium hydride (1.6 g; 60\% in mineral oil, $40 \mathrm{mmol}$ ) and closed with a septum. $n$-Hexane $(20 \mathrm{~mL})$ was injected by syringe and the suspension was stirred for $10 \mathrm{~min}$. Then, stirring was interrupted and the supernatant liquid was removed by syringe. THF (30 mL) and 3,4-dimethoxybenzaldehyde (3.32 g, $20.0 \mathrm{mmol})$, and methyltriphenylphosphonium bromide (10 g, $28 \mathrm{mmol}$ ) were added and the mixture was refluxed for $24 \mathrm{~h}$. After cooling in an ice bath, deionized water $(5 \mathrm{~mL})$ was added and the mixture was extracted with three $30 \mathrm{~mL}$ portions of ethyl acetate. The combined organic layers were washed with brine, dried with sodium sulfate and concentrated under reduced pressure. The crude product was purified by column chromatography (ethyl acetate $/ n$-hexane, $1: 9)$ to give $2.01 \mathrm{~g}(61 \%)$ of styrene $7 \mathbf{a}$ as a colorless liquid. The spectroscopic data agree with those described in the literature [22].

General procedure for the synthesis of dihydrostilbenes 8: In a glove-box under argon atmosphere, a $20 \mathrm{~mL}$ overpressure tube was charged with ketone $6(4.0 \mathrm{mmol})$, styrene 7 (8.0 mmol), $\left[\mathrm{Ru}(p \text {-cymene }) \mathrm{Cl}_{2}\right]_{2}(62.0 \mathrm{mg}, 0.1 \mathrm{mmol})$, $\mathrm{P}\left(4-\mathrm{CF}_{3} \mathrm{C}_{6} \mathrm{H}_{4}\right)_{3}(190 \mathrm{mg}, 0.6 \mathrm{mmol})$, and sodium formate ( $82 \mathrm{mg} ; 1.2 \mathrm{mmol})$. Freshly distilled toluene $(3 \mathrm{~mL}$ ) was added, and the mixture was kept in the sealed tube for 7 to 10 days at
140 to $150{ }^{\circ} \mathrm{C}$. After cooling to $25^{\circ} \mathrm{C}$, deionized water $(2 \mathrm{~mL})$ was added and the mixture was extracted with five $20 \mathrm{~mL}$ portions of ethyl acetate. The combined organic layers were washed with brine and dried with $\mathrm{MgSO}_{4}$. The solvent was removed in a rotary evaporator and the residue was purified by column chromatography. According to this procedure, the following compounds were obtained:

1 - [3,6- B is (benzyloxy)-2-(3,4-dimethoxyphenethyl)phenyl)]ethan-1-one (8a): Prepared from 2,4-bis(benzyloxy)acetophenone (6a, $760 \mathrm{mg}, 2.3 \mathrm{mmol})$ and 3,4dimethoxystyrene (7a, $860 \mathrm{mg}, 5.2 \mathrm{mmol})$ in $2 \mathrm{~mL}$ of toluene at $150{ }^{\circ} \mathrm{C}$ for $7 \mathrm{~d}$. The crude product was purified by column chromatography (silica gel; ethyl acetate $/ n$-hexane, $1: 7$ ) and 8a was obtained as a greenish syrup in $65 \%$ yield $(741 \mathrm{mg}) . R_{\mathrm{f}} 0.1$; ${ }^{1} \mathrm{H} \mathrm{NMR}\left(\mathrm{CDCl}_{3}, 600 \mathrm{MHz}\right) \delta 2.40(\mathrm{~s}, 3 \mathrm{H}), 2.80(\mathrm{~s}, 4 \mathrm{H}), 3.73$ $(\mathrm{s}, 3 \mathrm{H}), 3.84(\mathrm{~s}, 3 \mathrm{H}), 5.03(\mathrm{~s}, 2 \mathrm{H}), 5.04(\mathrm{~s}, 2 \mathrm{H}), 6.60(\mathrm{~d}, J=1.8$ $\mathrm{Hz}, 1 \mathrm{H}), 6.67-6.69(\mathrm{dd}, J=8.1,2.0 \mathrm{~Hz}, 1 \mathrm{H}), 6.74(\mathrm{~d}, J=8.1$ $\mathrm{Hz}, 1 \mathrm{H}), 6.77$ (d, $J=8.9 \mathrm{~Hz}, 1 \mathrm{H}), 6.85(\mathrm{~d}, J=8.9 \mathrm{~Hz}, 1 \mathrm{H})$, 7.31-7.41 (m, 8H), $7.45(\mathrm{~m}, 2 \mathrm{H}) ;{ }^{13} \mathrm{C} \mathrm{NMR}\left(\mathrm{CDCl}_{3}, 150 \mathrm{MHz}\right)$ $\delta 30.8,32.6,36.3,55.9,56.1,70.3,70.1,110.8,111.3,112.0$, $112.7,120.5,127.3,127.3,127.5,127.5,128.1,128.1,128.5$, $128.7,128.7,133.7,135.2,137.0,137.4,147.3,148.9,149.2$, 151.5, 205.4; HRMS (ESI): $[\mathrm{M}+\mathrm{H}]^{+}$calcd for $\mathrm{C}_{32} \mathrm{H}_{33} \mathrm{O}_{5}$, 497.2328; found, 497.2321.

1-[3,6-Bis(benzyloxy)-2-(4-methoxyphenethyl)phenyl]ethan1-one (8b): Prepared from 2,5-bis(benzyloxy)acetophenone (6a, $665 \mathrm{mg}, 2.0 \mathrm{mmol}$ ) and commercially available 4-methoxystyrene $(7 \mathbf{b}, 537 \mathrm{mg}, 4.0 \mathrm{mmol})$ in $1.5 \mathrm{~mL}$ of toluene at $145^{\circ} \mathrm{C}$ for $10 \mathrm{~d}$. The crude product was purified by column chromatography (silica gel; ethyl acetate/ $n$-hexane, $1: 18$ ) and $\mathbf{8 b}$ was obtained as a yellowish syrup in $68 \%$ yield $(633 \mathrm{mg}) ; R_{\mathrm{f}} 0.4$; ${ }^{1} \mathrm{H} \mathrm{NMR}\left(\mathrm{CDCl}_{3}, 600 \mathrm{MHz}\right) \delta 2.40(\mathrm{~s}, 3 \mathrm{H}), 2.80(\mathrm{~s}, 4 \mathrm{H}), 3.73$ $(\mathrm{s}, 3 \mathrm{H}), 5.03(\mathrm{~s}, 2 \mathrm{H}), 5.04(\mathrm{~s}, 2 \mathrm{H}), 6.60(\mathrm{~s}, 1 \mathrm{H}), 6.67-6.69(\mathrm{~m}$, $1 \mathrm{H}), 6.73-6.78(\mathrm{~m}, 2 \mathrm{H}), 6.85(\mathrm{~d}, J=8.9 \mathrm{~Hz}, 1 \mathrm{H}), 7.31-7.41(\mathrm{~m}$, $8 \mathrm{H}), 7.45(\mathrm{~m}, 2 \mathrm{H}) ;{ }^{13} \mathrm{C} \mathrm{NMR}\left(\mathrm{CDCl}_{3}, 150 \mathrm{MHz}\right) \delta 30.8,32.6$, $36.3,55.9,70.3,70.1,110.8,111.3,112.0,112.7,120.5,127.3$, $127.3,127.5,127.5,128.1,128.1,128.5,128.7,128.7,128.7$, 128.7, 133.7, 135.2, 137.0, 137.4, 147.3, 148.9, 149.2, 151.5, 205.4; HRMS (ESI): $[\mathrm{M}+\mathrm{H}]^{+}$calcd for $\mathrm{C}_{31} \mathrm{H}_{31} \mathrm{O}_{4}, 467.2222$; found, 467.2216.

\section{1-[3-(Benzyloxy)-6-methoxy-2-(4-methoxyphen-ethyl)phe-} nyl]ethan-1-one (8c): Prepared from 5-(benzyloxy)-2methoxyacetophenone $(\mathbf{6 b}, 513 \mathrm{mg}, 2.0 \mathrm{mmol})$ and commercially available 4-methoxystyrene $(7 \mathbf{b}, 537 \mathrm{mg}, 4.0 \mathrm{mmol})$. The crude product was purified by column chromatography (silica gel; ethyl acetate $/ n$-hexane, $1: 18)$ and $\mathbf{8 c}$ was obtained as a greenish syrup in $73 \%$ yield $(571 \mathrm{mg}) ; R_{\mathrm{f}} 0.3 ;{ }^{1} \mathrm{H}$ NMR $\left(\mathrm{CDCl}_{3}, 600 \mathrm{MHz}\right) \delta 2.39(\mathrm{~s}, 3 \mathrm{H}), 2.79(\mathrm{~m}, 4 \mathrm{H}), 3.697(\mathrm{~s}, 3 \mathrm{H})$, 
$3.698(\mathrm{~s}, 3 \mathrm{H}), 5.06(\mathrm{~s}, 2 \mathrm{H}), 6.73(\mathrm{~d}, J=8.5 \mathrm{~Hz}, 1 \mathrm{H}), 6.78(\mathrm{~d}, J=$ $8.5 \mathrm{~Hz}, 2 \mathrm{H}), 6.88(\mathrm{~d}, J=8.5 \mathrm{~Hz}, 1 \mathrm{H}), 7.03(\mathrm{~d}, J=8.3 \mathrm{~Hz}, 2 \mathrm{H})$, 7.35 (t, $J=7.3 \mathrm{~Hz}, 1 \mathrm{H}), 7.41(\mathrm{t}, J=7.4 \mathrm{~Hz}, 2 \mathrm{H}), 7.45$ (d, $J=$ $7.1 \mathrm{~Hz}, 2 \mathrm{H}) ;{ }^{13} \mathrm{C} \mathrm{NMR}\left(\mathrm{CDCl}_{3}, 150 \mathrm{MHz}\right) \delta 30.8,32.5,35.9$, 55.4, 56.1, 70.8, 109.1, 112.8, 113.9, 113.9, 127.3, 127.3, 128.0, $128.5,128.7,128.7,129.6,133.1,134.7,137.5,150.1,151.2$, 158.0, 205.5; HRMS (ESI): $[\mathrm{M}+\mathrm{H}]^{+}$calcd for $\mathrm{C}_{25} \mathrm{H}_{27} \mathrm{O}_{4}$, 391.1909; found, 391.1905 .

\section{1-[2-(3,4-Dimethoxyphenethyl)-3,6-dimethoxyphenyl]ethan-} 1-one (8d): Prepared from 2,5-dimethoxyacetophenone (6c, $168 \mathrm{mg}, 1.04 \mathrm{mmol}$ ) and 3,4-dimethoxystyrene (7a, $348 \mathrm{mg}$, $2.0 \mathrm{mmol}$ ) in $1 \mathrm{~mL}$ of toluene at $145^{\circ} \mathrm{C}$ for $7 \mathrm{~d}$. The crude product was purified by column chromatography (silica gel; ethyl acetate $/ n$-hexane, 1:9) and $\mathbf{8 d}$ was obtained as an orange syrup in $40 \%$ yield $(145 \mathrm{mg}) ; R_{\mathrm{f}} 0.35 ;{ }^{1} \mathrm{H} \mathrm{NMR}\left(\mathrm{CDCl}_{3}, 600 \mathrm{MHz}\right) \delta$ $2.34(\mathrm{~s}, 3 \mathrm{H}), 2.75(\mathrm{~s}, 4 \mathrm{H}), 3.76(\mathrm{~s}, 3 \mathrm{H}), 3.80(\mathrm{~s}, 3 \mathrm{H}), 3.84(\mathrm{~s}$, $3 \mathrm{H}), 3.85(\mathrm{~s}, 3 \mathrm{H}), 6.69(\mathrm{~s}, 1 \mathrm{H}), 6.72-6.74(\mathrm{~d}, J=8.7 \mathrm{~Hz}, 2 \mathrm{H})$, $6.77-6.78(\mathrm{~d}, J=8.1 \mathrm{~Hz}, 1 \mathrm{H}), 6.81(\mathrm{~d}, J=8.9 \mathrm{~Hz}, 1 \mathrm{H})$; ${ }^{13} \mathrm{C} \mathrm{NMR}\left(\mathrm{CDCl}_{3}, 150 \mathrm{MHz}\right) \delta 30.1,32.4,36.1,55.9,56.1$, $56.1,109.1,111.3,111.4,112.1,120.5,128.0,133.0,135.2$, 147.3, 148.8, 149.8, 151.1, 205.5; HRMS (ESI): $[\mathrm{M}+\mathrm{H}]^{+}$calcd for $\mathrm{C}_{20} \mathrm{H}_{25} \mathrm{O}_{5}, 345.1702$; found 345.1697; anal. calcd for $\mathrm{C}_{20} \mathrm{H}_{24} \mathrm{O}_{5}$ : C, 69.75; H, 7.02; found: C, 69.56; H, 6.73.

General procedure for the synthesis of phenols 9-11 by hydrogenolytic cleavage of benzyl ether protecting groups: An autoclave was equipped with a stirring bar and charged with O-protected dihydrostilbenes $\mathbf{8 a}, \mathbf{b}(0.8 \mathrm{mmol})$, palladium on charcoal $(50 \mathrm{mg})$ and ethyl acetate $(12 \mathrm{~mL})$. The autoclave was connected to the hydrogen source and rinsed carefully with hydrogen. Thereafter, the mixture was stirred at $25^{\circ} \mathrm{C}$ and 3 bar hydrogen pressure for 1-3 d. Then, the mixture was filtered through a frit filled with silica gel that was rinsed five times with ethyl acetate. The combined filtrates were concentrated under reduced pressure and the crude product was purified by column chromatography using mixtures of ethyl acetate and $n$-hexane. According to this procedure, the following compounds were obtained:

1-[2-(3,4-Dimethoxyphenethyl)-3,6-dihydroxyphenyl)ethan1-one (9): Prepared from 8a (741 mg, $1.5 \mathrm{mmol})$, palladium on charcoal $(200 \mathrm{mg})$ in ethyl acetate $(15 \mathrm{~mL})$ at 3 bar hydrogen pressure for $72 \mathrm{~h}$. The crude product was purified by column chromatography (silica gel; ethyl acetate $/ n$-hexane, $1: 7$ ) to give 9 as a greenish syrup in $75 \%$ yield $(356 \mathrm{mg}) ; R_{\mathrm{f}} 0.1 ;{ }^{1} \mathrm{H}$ NMR $\left(\mathrm{CDCl}_{3}, 600 \mathrm{MHz}\right) \delta 2.63(\mathrm{~s}, 3 \mathrm{H}), 2.87(\mathrm{dd}, J=9.0,6.8 \mathrm{~Hz}$, 2H), 3.09 (dd, $J=9.0,6.8 \mathrm{~Hz}, 2 \mathrm{H}), 3.83$ (s, 3H), 3.85 (s, 3H), 4.41 (br s, 1H), $6.64(\mathrm{~d}, J=1.9 \mathrm{~Hz}, 1 \mathrm{H}), 6.72-6.75(\mathrm{~m}, 2 \mathrm{H})$, $6.79(\mathrm{~d}, J=8.00 \mathrm{~Hz}, 1 \mathrm{H}), 6.83(\mathrm{~d}, J=8.9 \mathrm{~Hz}, 1 \mathrm{H}), 9.35$ (br s, $1 \mathrm{H}) ;{ }^{13} \mathrm{C} \mathrm{NMR}\left(\mathrm{CDCl}_{3}, 150 \mathrm{MHz}\right) \delta 30.6,32.7,36.1,56.0$,
56.1, 111.5, 111.9, 116.3, 120.3, 121.8, 125.2, 127.5, 134.1, 147.0, 147.7, 149.1, 152.9, 205.9; HRMS (ESI): $[\mathrm{M}+\mathrm{H}]^{+}$calcd for $\mathrm{C}_{18} \mathrm{H}_{21} \mathrm{O}_{5}, 317.1389$; found, 317.1384 .

1-[3,6-Dihydroxy-2-(4-methoxyphenethyl)phenyl]ethan-1one (10): Prepared from $\mathbf{8 b}(510 \mathrm{mg}, 1.1 \mathrm{mmol})$, palladium on charcoal $(135 \mathrm{mg})$ in ethyl acetate $(15 \mathrm{~mL})$ at 3 bar hydrogen pressure for $25 \mathrm{~h}$. The crude product was purified by column chromatography (silica gel; ethyl acetate/ $n$-hexane, $1: 7$ ) to give 10 (204 $\mathrm{mg}, 65 \%)$ as a greenish-brownish syrup; $R_{\mathrm{f}} 0.12$; ${ }^{1} \mathrm{H} \mathrm{NMR}\left(\mathrm{CDCl}_{3}, 600 \mathrm{MHz}\right) \delta 2.64(\mathrm{~s}, 3 \mathrm{H}), 2.85-2.87(\mathrm{~m}, 2 \mathrm{H})$, 3.06-3.09 (m, 2H), $3.79(\mathrm{~s}, 3 \mathrm{H}), 4.45$ (br s, 1H), $6.73(\mathrm{~d}, J=$ $6.73 \mathrm{~Hz}, 1 \mathrm{H}), 6.83-6.85(\mathrm{~m}, 3 \mathrm{H}), 7.10(\mathrm{~d}, J=7.1 \mathrm{~Hz}, 2 \mathrm{H})$; ${ }^{13} \mathrm{C}$ NMR $\left(\mathrm{CDCl}_{3}, 150 \mathrm{MHz}\right) \delta 30.8,32.7,35.6,55.5,114.2$, 114.2, 116.3, 121.8, 125.0, 127.6, 129.4, 129.4, 133.6, 146.0, 153.1, 158.3, 206.0; HRMS (ESI): $[\mathrm{M}+\mathrm{H}]^{+}$calcd for $\mathrm{C}_{17} \mathrm{H}_{19} \mathrm{O}_{4}, 287.1283$; found, 287.1279 .

A forerun in the column chromatography contained monodeprotected 1-[3-(benzyloxy)-6-hydroxy-2-(4-methoxyphenethyl)phenyl]ethan-1-one (11) that was still contaminated with a small amount of hydroquinone 10. Yield: $68 \mathrm{mg}(16 \%) ; R_{\mathrm{f}} 0.3$; ${ }^{1} \mathrm{H} \mathrm{NMR}\left(\mathrm{CDCl}_{3}, 600 \mathrm{MHz}\right) \delta 2.65(\mathrm{~s}, 3 \mathrm{H}), 2.82-2.85(\mathrm{~m}, 2 \mathrm{H})$, 3.04-3.09 (m, 2H), $3.78(\mathrm{~s}, 3 \mathrm{H}), 5.02(\mathrm{~s}, 2 \mathrm{H}), 6.81-6.83(\mathrm{~m}$, $3 \mathrm{H}), 6.99(\mathrm{~d}, J=8.2 \mathrm{~Hz}, 2 \mathrm{H}), 7.13-7.16(\mathrm{~m}, 3 \mathrm{H}), 7.35-7.37(\mathrm{~m}$, $1 \mathrm{H}), 7.44(\mathrm{~d}, 2 \mathrm{H}), 9.31$ (br s, $1 \mathrm{H}) ;{ }^{13} \mathrm{C} \mathrm{NMR}\left(\mathrm{CDCl}_{3}\right.$, $150 \mathrm{MHz}) \delta 32.7,35.4,35.8,55.4,71.6,114.0,114.0,115.9$, $118.7,118.7,121.4,126.8,127.6,128.2,128.8,129.4,129.8$, $130.5,134.0,137.5,152.5,154.6,158.1,205.2$; ESIMS $\mathrm{m} / \mathrm{z}$ (\%): $377.2[\mathrm{M}+1](100)$; HRMS (ESI): $[\mathrm{M}+\mathrm{H}]^{+}$calcd for $\mathrm{C}_{24} \mathrm{H}_{25} \mathrm{O}_{4}, 377.1753$; found, 377.1748 .

$(2 R, 3 R, 4 S, 5 R, 6 R)-2$-(Acetoxymethyl)-6-[3-acetyl-2-(3,4dimethoxyphenethyl)-4-hydroxyphenoxy] tetrahydro-2Hpyran-3,4,5-triyl triacetate (12): A $50 \mathrm{~mL}$ two-necked flask was equipped with a stirring bar and a connection to the combined nitrogen/vacuum line. The flask was charged with dihydrostilbene 9 (330 mg, $1.04 \mathrm{mmol})$ and $\beta$-glucose pentaacetate $(814 \mathrm{mg}, 2.08 \mathrm{mmol})$ and closed with a septum. The air in the flask was replaced by nitrogen. Then, dichloromethane $(4 \mathrm{~mL})$ and boron trifluoride etherate $(0.4 \mathrm{~mL}, 3.12 \mathrm{mmol})$ were injected by syringe. The mixture was stirred at $25{ }^{\circ} \mathrm{C}$ for $2 \mathrm{~d}$. Thereafter, saturated aqueous sodium hydrogen carbonate $(10 \mathrm{~mL})$ was added and the mixture was extracted five times with $15 \mathrm{~mL}$ portions of dichloromethane. The combined organic layers were washed with brine and dried with magnesium sulfate. The solvent was removed in a rotary evaporator and the crude product $(1.08 \mathrm{~g})$ was purified by column chromatography (silica gel; ethyl acetate/ $n$-hexane, $1: 4$ to $1: 2$ ) to give $91 \mathrm{mg}$ (14\%) of pure glycoside 12 as a colorless syrup. ${ }^{1} \mathrm{H}$ NMR $\left(\mathrm{CDCl}_{3}, 600 \mathrm{MHz}\right) \delta 2.04(\mathrm{~s}, 3 \mathrm{H}), 2.06(\mathrm{~s}, 3 \mathrm{H}), 2.07(\mathrm{~s}, 3 \mathrm{H})$, 
$2.08(\mathrm{~s}, 3 \mathrm{H}), 2.64(\mathrm{~s}, 3 \mathrm{H}), 2.77-2.82(\mathrm{~m}, 1 \mathrm{H}), 2.92-2.97(\mathrm{~m}$, $1 \mathrm{H}), 3.08-3.14(\mathrm{~m}, 2 \mathrm{H}), 3.85(\mathrm{~s}, 3 \mathrm{H}), 3.87(\mathrm{~s}, 3 \mathrm{H}), 4.0-4.14(\mathrm{~m}$, 2H), $4.26(\mathrm{dd}, J=12.4,4.7 \mathrm{~Hz}, 1 \mathrm{H}), 5.10(\mathrm{ddd}, J=10.3,3.8$, $1.1 \mathrm{~Hz}, 1 \mathrm{H}), 5.18(\mathrm{t}, J=5.2 \mathrm{~Hz}, 1 \mathrm{H}), 5.59$ (d, $J=3.5 \mathrm{~Hz}, 1 \mathrm{H})$, $5.75(\mathrm{t}, J=10.2 \mathrm{~Hz}, 1 \mathrm{H}), 6.71(\mathrm{~s}, 1 \mathrm{H}), 6.78(\mathrm{dd}, J=9.0,1.1 \mathrm{~Hz}$, $1 \mathrm{H}), 6.82-6.85(\mathrm{~m}, 2 \mathrm{H}), 7.28(\mathrm{dd}, J=9.1,1.0 \mathrm{~Hz}, 1 \mathrm{H}), 8.99$ (brs, $1 \mathrm{H}) ;{ }^{13} \mathrm{C} \mathrm{NMR}\left(\mathrm{CDCl}_{3}, 150 \mathrm{MHz}\right) \delta 20.7,20.8,20.8$, 20.9, 31.0, 32.7, 36.6, 56.0, 56.1, 60.6, 61.8, 68.2, 68.4, 70.2, $70.4,95.8,111.7,116.2,120.5,120.6,120.8,124.7,134.0$, 147.7, 149.1, 170.1, 170.7, 205.6, 206.1, 206.2, 210.7, 213.0; HRMS: $[\mathrm{M}+\mathrm{H}]^{+}$calcd for $\mathrm{C}_{32} \mathrm{H}_{38} \mathrm{NaO}_{14}, 669.2159$; found, 669.2154 .

epi-Scorzodihydrostilbene D (13): A mixture of 12 (18 mg, $0.03 \mathrm{mmol})$, methanol $(1 \mathrm{~mL})$ and sodium ethoxide $(3 \mathrm{mg}$, $0.06 \mathrm{mmol}$ ) was stirred at $25{ }^{\circ} \mathrm{C}$ for $4 \mathrm{~h}$. The mixture was filtered and the filtrate was concentrated under reduced pressure. The residue was purified by semi-preparative reversedphase HPLC (methanol-water gradient) to give $11 \mathrm{mg}$ (17\%) of pure epi-scorzodihydrostilbene $\mathrm{D}(\mathbf{1 3})$ as a colorless syrup. ${ }^{1} \mathrm{H}$ NMR $\left(\mathrm{CD}_{3} \mathrm{OD}, 600 \mathrm{MHz}\right) \delta 2.33(\mathrm{~s}, 3 \mathrm{H}), 2.69-2.99(\mathrm{~m}$, $4 \mathrm{H}), 3.45$ (t, $J=8.9 \mathrm{~Hz}, 1 \mathrm{H}), 3.63(\mathrm{dd}, J=9.6 \mathrm{~Hz}, 3.3 \mathrm{~Hz}, 1 \mathrm{H})$, $3.72(\mathrm{~m}, 2 \mathrm{H}), 3.77-3.83(\mathrm{~m}, 7 \mathrm{H}), 3.95(\mathrm{t}, J=9.3 \mathrm{~Hz}, 1 \mathrm{H}), 5.40$ (s, 1H), $6.67(\mathrm{~d}, J=8.9 \mathrm{~Hz}, 1 \mathrm{H}), 6.76(\mathrm{~d}, J=8.0 \mathrm{~Hz}, 1 \mathrm{H}), 6.81$ (s, 1H), 6.84 (d, $J=7.9 \mathrm{~Hz}, 1 \mathrm{H}), 7.21$ (d, $J=8.8 \mathrm{~Hz}, 1 \mathrm{H})$; ${ }^{13} \mathrm{C}$ NMR $\left(\mathrm{CD}_{3} \mathrm{OD}, 150 \mathrm{MHz}\right) \delta 31.3,32.4,37.3,56.5,56.6$, $62.5,68.5,71.7,73.4,74.5,75.2,100.2,113.2,113.9,114.7$, 118.6, 121.9, 130.2, 131.8, 136.9, 148.6, 150.1, 150.2, 208.1; HRMS: $[\mathrm{M}+\mathrm{H}]^{+}$calcd for $\mathrm{C}_{24} \mathrm{H}_{30} \mathrm{NaO}_{10}, 501.1737$; found, 501.1724 .

\section{Supporting Information}

\section{Supporting Information File 1}

${ }^{1} \mathrm{H}$ NMR and ${ }^{13} \mathrm{C}$ NMR spectra of all new compounds. [https://www.beilstein-journals.org/bjoc/content/ supplementary/1860-5397-15-56-S1.pdf]

\section{Acknowledgements}

We would like to thank Prof. Dr. Peter Proksch and Dr. Andreas Marmann (Institute of Pharmaceutical Biology and Biotechnology, University of Düsseldorf) for fruitful discussions and help with HPLC separation.

\section{References}

1. Xiao, K.; Zhang, H.-J.; Xuan, L.-J.; Zhang, J.; Xu, Y.-M.; Bai, D.-L. Stilbenoids: Chemistry and bioactivities. In Studies in Natural Products Chemistry; Atta-ur-Rahman, Ed.; Elsevier: Amsterdam, 2008; Vol. 34, pp 453-646.

See for a review.
2. Grubov, V. I. Key to the Vascular Plants of Mongolia; Nauka: Leningrad, 1982; pp 263-264.

3. Gubanov, I. A. The conspectus of flora outer Mongolia (vascular plants); Valang: Moscow, 1996; p 106.

4. Ligaa, U. Medicinal Plants from Mongolia Used in Mongolian Traditional Medicine; KSA Press: Ulaanbaatar, 1996; p 337.

5. Wang, Y.; Edrada-Ebel, R.; Tsevegsuren, N.; Sendker, J.; Braun, M.; Wray, V.; Lin, W.; Proksch, P. J. Nat. Prod. 2009, 72, 671-675. doi:10.1021/np800782f

6. Arockiam, P. B.; Bruneau, C.; Dixneuf, P. H. Chem. Rev. 2012, 112, 5879-5918. doi:10.1021/cr300153j

See for a more recent overview on ruthenium(II)-catalyzed $\mathrm{C}-\mathrm{H}$ bond activation and functionalization.

7. Venkateswarlu, S.; Raju, M. S. S.; Subbaraju, G. V. Biosci., Biotechnol., Biochem. 2002, 66, 2236-2238. doi:10.1271/bbb.66.2236

8. Zhang, W.-G.; Zhao, R.; Ren, J.; Ren, L.-X.; Lin, J.-G.; Liu, D.-L.; Wu, Y.-L.; Yao, X.-S. Arch. Pharm. (Weinheim, Ger.) 2007, 340, 244-250. doi:10.1002/ardp.200600146

9. Moodie, L. W. K.; Trepos, R.; Cervin, G.; Bråthen, K. A.; Lindgård, B.; Reiersen, R.; Cahill, P.; Pavia, H.; Hellio, C.; Svenson, J. J. Nat. Prod. 2017, 80, 2001-2011. doi:10.1021/acs.jnatprod.7b00129

10. Weimann, K. Erste Synthese eines Scorzodihydrostilben-Aglycons und Glycosylierung zu Epi-Scorzodihydrostilben D. Ph.D. Thesis, Heinrich-Heine-Universität, Düsseldorf, Germany, 2014.

11. Murai, S.; Kakiuchi, F.; Sekine, S.; Tanaka, Y.; Kamatani, A.; Sonoda, M.; Chatani, N. Nature 1993, 366, 529-531. doi:10.1038/366529a0

12. Murai, S.; Kakiuchi, F.; Sekine, S.; Tanaka, Y.; Kamatani, A.; Sonoda, M.; Chatani, N. Pure Appl. Chem. 1994, 66, 1527-1534. doi:10.1351/pac199466071527

13. Kakiuchi, F.; Sekine, S.; Tanaka, Y.; Kamatani, A.; Sonoda, M.; Chatani, N.; Murai, S. Bull. Chem. Soc. Jpn. 1995, 68, 62-83. doi:10.1246/bcsj.68.62

14. Murai, S.; Chatani, N.; Kakiuchi, F. Pure Appl. Chem. 1997, 69, 589-594. doi:10.1351/pac199769030589

15. Lewis, L. N.; Smith, J. F. J. Am. Chem. Soc. 1986, 108, 2728-2735. doi:10.1021/ja00270a036

See for an early report on ruthenium-catalyzed $\mathrm{C}-\mathrm{C}$ bond formation via ortho-metalated phenol.

16. Martinez, R.; Genet, J.-P.; Darses, S. Chem. Commun. 2008, 3855-3857. doi:10.1039/b806121a

17. Greene, T. W.; Wuts, P. G. M. Protective Groups in Organic Synthesis, 2nd ed.; Wiley: New York, 1991; pp 156-158.

18. Augustine, R. L. Catalytic Hydrogenation; Marcel Dekker: New York, 1965; pp 135-136.

19. Helferich, B.; Schmitz-Hillebrecht, E. Ber. Dtsch. Chem. Ges. B 1933, 66, 378-383. doi:10.1002/cber.19330660313

20. Cocinero, E. J.; Gamblin, D. P.; Davis, B. G.; Simons, J. P. J. Am. Chem. Soc. 2009, 131, 11117-11123. doi:10.1021/ja903322w See for a recent procedure for a boron trifluoride-mediated synthesis of 1-phenyl-2, 3, 4, 6-tetra-O-acetyl-ß-D-glucopyranoside from phenol and glucose peracetate.

21. Giles, R. G. F.; Joll, C. A. J. Chem. Soc., Perkin Trans. 11999 , 3039-3048. doi:10.1039/a901457h

22. Sun, B.; Hoshino, J.; Jermihov, K.; Marler, L.; Pezzuto, J. M.; Mesecar, A. D.; Cushman, M. Bioorg. Med. Chem. 2010, 18, 5352-5366. doi:10.1016/j.bmc.2010.05.042 


\section{License and Terms}

This is an Open Access article under the terms of the Creative Commons Attribution License (http://creativecommons.org/licenses/by/4.0). Please note that the reuse, redistribution and reproduction in particular requires that the authors and source are credited.

The license is subject to the Beilstein Journal of Organic Chemistry terms and conditions:

(https://www.beilstein-journals.org/bjoc)

The definitive version of this article is the electronic one which can be found at:

$\underline{\text { doi: } 10.3762 / \text { bjoc. } 15.56}$ 